\title{
Радіологічні та патогістологічні методи оцінки периферичного сегмента артеріального русла для об'єктивізації синдрому діабетичної стопи
}

\author{
Т. Л. Ленчук, В. М. Мацькевич, С. М. Василюк
}

Івано-Франківський національний медичний університет

\section{Radiological and pathohistological methods of estimation of peripheral segment of the arterial bed for objectivization of the diabetic foot syndrome}

\author{
T. L. Lenchuk, V. M. Matskevych, S. M. Vasyliuk \\ Ivano-Frankivsk National Medical University
}

\section{Реферат}

Мета. Підвищення інформативності мультидетекторної комп'ютерно-томографічної ангіографії (МДКТА) та гістоморфометрії судин нижніх кінцівок (НК) шляхом їх порівняння та визначення клінічної цінності кожного зокрема у пацієнтів із синдромом діабетичної стопи (СДС).

Матеріали і методи. Обстежено 80 хворих (усі чоловіки) із СДС, яким проведено передопераційну МДКТА НК та гістоморфометрію судинних структур післяопераційного біоматеріалу.

Результати. МДКТА мала нижчу чутливість $(31,3 \%)$ щодо визначення виду атеросклеротичної бляшки порівняно 3 гістологічним дослідженням, за даними якого навіть у певній вказаній стадії чітко встановлювали початок чи зрілість названого патоморфологічного процесу. І за допомогою МДКТА, і за допомогою прямої морфометрії отримали високоінформативну кількісну оцінку анатомічних розмірів досліджуваних артерій (площа під ROC-кривою дорівнювала 0,994 та 0,875 відповідно), якщо зважати на статистично достовірні результати якості діагностичних тестів згідно з експертною шкалою класифікаторів.

Висновки. МДКТА має високу клінічну значущість у виявленні власне атеросклеротичних бляшок, але іiі не можна вважати «золотим стандартом» щодо диференціації стадій атеросклерозу у пацієнтів з діабетичною макроангіопатією. Пряма морфометрія артеріальних структур діабетичної стопи поступалась щодо операційних характеристик МдКТА через складність штучного відтворення гомеостазу артеріального русла, що вплинуло на стан досліджуваних анатомічних структур.

Ключові слова: діабетична макроангіопатія; мультидетекторна комп’ютерно-томографічна ангіографія; пряма морфометрія; атеросклероз.

Abstract

Objective. Enhancing of informativity of multidetector computed-tomographic angiography (MDCTA) and histomorphometry of the lower extremities (LE) vessels, using their comparison and determination of clinical validity, including the patients, suffering a diabetic foot syndrome (DFS)

Materials and methods. There were examined 80 patients (all are men) with DFS, to whom preoperative MDCTA of LE and histomorphometry of vascular structures of postoperative biomaterial were done.

Results. MDCTA have had lower sensitivity (31.3\%) vs histological investigation, concerning determination of the atherosclerotic pluck kind as well as in accordance to data about a certain known stage of the beginning or maturing of this named pathomorphological process. There was established, that using MDCTA and a direct morphometry it is possible to gain a highly informative quantitative data on anatomic dimensions of the arteries investigated (the square under the ROC-curve equaled 0.994 and 0.875 accordingly), if to rely on statistically trustworthy results of the diagnostic tests quality in accordance to the experts scale of classificators.

Conclusion. MDCTA has high significance in diagnosis of atherosclerotic plucks, but it may not be regarded a «golden standard» for differentiation of the atherosclerosis stages in patients, suffering diabetic angiopathy. Direct morphometry of arterial structures of the diabetic foot gave away the concerning operating characteristics of MDCTA because of complexity of a process of artificial restoration of the arterial bed hemostasisa, what have impacted the state of the anatomic structures investigated Keywords: diabetic macroangiopathy; multidetector computed-tomographic angiography; direct morphometry; atherosclerosis,

Ішемія НК є рівнозначною нейропатії та інфекційному приєднаному компоненту у розвитку гангрени стопи, ускладнення якої часто призводять до виконання ампутації. Але, окрім вивчення стану судин, не менше значення має стан кістки у прогнозуванні подальшого лікування. Завдяки низькому рівню метаболізму кісткової тканини важливим є збереження достатніх джерел іï кровопостачання. Комплексно внутрішньокісткове та періостальне судинні сплетення можуть самостійно забезпечити життєздатність компактної кістки на всю ії товщину. На сьогодні клінічно та експериментально доведена провідна роль кровообігу в репаративній регенерації кісткової тка- 
нини $[1,2]$. Ранні візуалізаційні дослідження є вирішальними для поліпшення загоєння діабетичної виразки НК та запобігання ампутації. Застосування МДКТА НК дає змогу об'єктивно оцінити діаметр та просвіт артерії при пошаровому аналізі та багатоплощинній і об'ємній реконструкціях із визначенням протяжності медіакальцинозу Менкеберга та щільності атеросклеротичної бляшки. Отримані дані становлять клінічну цінність для хірурга у підготовці хворого до часткової ампутації стопи. За даними гістологічного вивчення постампутаційного матеріалу встановлюють стадію розвитку атеросклерозу та якісно визначають ступінь структурної перебудови судинної стінки. Маючи патоморфологічний висновок, лікар може краще спланувати лікування пацієнта після операції. Поєднання обох діагностичних методів дає можливість окреслити та сформувати зворотний взаємозв'язок ступеня життездатності тканин кінцівки у перспективі.

Існує нагальна потреба змінити парадигму у діагностуванні та лікуванні діабетичної стопи. Оскільки існуючих даних обмаль, потрібні фокусні мультидисциплінарні дослідження щодо цінності прогностичних тестів для подальшого вибору цілеспрямованої стратегії комплексної діагностики та лікування пацієнтів [3].

Мета дослідження: підвищення інформативності методів МДКТА та гістоморфометрії судин НК шляхом їх порівняння та визначення клінічної цінності кожного зокрема у пацієнтів із СДС.

\section{Матеріали і методи дослідження}

Протягом 10 років обстежено 80 пацієнтів чоловічої статі з діабетичною макроангіопатією НК, яким згідно 3 критеріями включення виконали ампутацію стопи (64) чи всієї кінцівки (16). Усі пацієнти мали цукровий діабет 2-го типу тривалістю 18 - 20 років. Як групу порівняння було обрано 20 осіб з травмами НК, яким була показана часткова ампутація однієї або обох НК. Медіана віку пацієнтів становила 59,5 року, маси тіла - 76,4 кг. Усім пацієнтам проводили МДКТА в таких режимах: товщина зрізу 0,5 мм × 32, 0,5 мм × 64; пітч-стандарт (Pitch Factor 0813/ Helical Pitch 65,0); час повного обертання трубки - 0,5 c.

Пацієнтам, яким судинний хірург призначив МДКТА, надавали для підпису інформовану згоду для ознайомлення стосовно контрастного середника (неіонного мономерного контрасту йогексол 300). Томографію починали від біфуркації аорти, коли щільність тригера досягала 180 одиниць Хаусфілда (HU). Згідно з протоколом «CT Vascular Femoral Run-off» після затримки на клапані у 2 с відбувалась перша серія сканувань, які починались від вищого купола діафрагми і закінчувались нижче колін. Через 11,3 с після введення контрасту відбувалась друга серія сканувань, які починались нижче колін і закінчувались нижче гомілковостопних суглобів (із захопленням пальців стопи). Досліджуючи судини, визначали такі показники: діаметр артерії на поперечному зрізі за допомогою функції «Ruler» (мм); площа поперечного зрізу артерії за допомогою функції «Vessel Area» $\left(\mathrm{мм}^{2}\right)$; співвідношення стінка/просвіт артерій за допомогою функції «Wall/ Lumen Ratio (Area)» (відсоткова пропорція); площа атеросклеротичної бляшки на томографічному перерізі за допомогою функції «Plaque burden» (у відсотках відносно площі поперечного зрізу артеріï) та функції «Plaque Area» $\left(\mathrm{Mм}^{2}\right)$; вид атеросклеротичної бляшки згідно з показником щільності, визначеним в HU з урахуванням стандартного відхилення (SD), з кольоровим автоматизованим маркуванням для полегшення сприйняття, за якого кожну атеросклеротичну бляшку можна класифікувати як жирову смужку («-»100 - 49 HU) - червоний колір маркування, «Plaque 1», фіброзну бляшку (50 - 149 HU) - синій колір, «Plaque 2», ускладнену бляшку з вогнищами кальцинації (150 - $1300 \mathrm{HU})$ - жовтий колір, «Plaque 3».

Значення абсолютної похибки вимірювання отримували автоматично, виконуючи заміри, оскільки ця функція включена в комп'ютерну програму апарата постпроцесингової обробки [4].

Надалі процес дослідження відбувався в патогістологічній лабораторії, куди надходили післяопераційні тканини. Безпосередню (пряму, лінійну) морфометрію виконували на нативному біоматеріалі без введення 40\% водного розчину формальдегіду, який спричиняє дегідратацію і, як наслідок, затвердіння стінок артерій. Ін'єкційну масу готували безпосередньо перед наливкою артерій, а саме: 10 г желатину розчиняли у 100 мл теплої води, додавали 6,5 г акрилу. Отриману суміш постійно перемішували скляним розмішувачем, а перед іiі введенням промивали артеріальне русло теплим $2 \%$ розчином нашатирного спирту, щоб видалити кров'яні згустки. Для уникнення спотворення розмірів артерій внаслідок їх розширення не додавали до ін'єкційної маси 0,2\% розчину азотнокислого натрію. Артерії наливали за допомогою скляних канюль за загальноприйнятою методикою [5]. Після введення фарбувальних мас робили масаж біоматеріалу для кращого заповнення артерій. Надалі налиті тканини охолоджували та фіксували у 10\% розчині формаліну. Отримавши готовий макропрепарат, морфометричні показники визначали за допомогою циркуля та металічної міліметрової лінійки. Розраховували абсолютну похибку засобу вимірювання та отримували достовірний результат за формулою: A= a $\pm \Delta$, де $\mathrm{A}$ - результат вимірювання з урахуванням похибки; а - значення фізичної величини, отриманої безпосереднім вимірюванням; $\Delta \mathrm{a}$ - похибка засобу вимірювання, яка становить половину ціни поділки шкали вимірювального приладу.

Отримані показники безпосередніх замірів артерій біоматеріалу та попередні цифрові автоматичні дані МДКТА вносили в таблицю для ретроспективного аналізу точності результатів.

Аналізували й опрацьовували статистичні дані з використанням пакета прикладних програм STATISTICA 5.0, MS Excel XP та MedCalc. Для розрахунку серединного значення впорядкованого масиву чисел абсолютних величин визначали середнє арифметичне як Mean \pm SD (Min-Max), оскільки не було викидів, які б впливали на вибірку. Для вираження екстенсивних показників використовували відсоткове співвідношення частки до цілого. Порівнювали відносні величини, які вимірювали в номінальній або порядковій шкалі, за допомогою критерію $\chi^{2}$ (хі-квадрат) Пірсона, розрахунку поправки Йєйтса та точного критерію Фішера. Значущість оцінювали на рівні 5\%. Для оцін- 
ки інформативності діагностичного методу використовували такі операційні характеристики: чутливість, специфічність, точність, прогностична позитивна цінність тесту (ППЦ) та прогностична негативна цінність (ПНЦ) тесту. Для порівняння інформативності діагностичних тестів будували ROC-криві, які потім порівнювали, що давало змогу оцінити якість бінарної класифікації. Кількісну інтерпретацію кривої помилок здійснювали, вираховуючи площу під ROC-кривою.

\section{Результати}

Усі пацієнти на момент обстеження мали гангренозні зміни м'яких тканин дистальних відділів стопи. У 9 (11,25\%) пацієнтів спостерігали невеликі сухі трофічні виразки незначного розміру на підошовній поверхні однієї чи обох стоп без серозних виділень. У 71 (88,75\%) пацієнта були виразки, ускладнені нагноєнням з незначними серозними виділеннями, які мали неприємний запах. У всіх пацієнтів виявлено двостороннє ураження периферичного сегмента судинного русла НК, додатково у $22,5 \%$ - односторонне і у 77,5\% - двостороннє ураження інших сегментів з розвиненою сіткою колатералей. Визначаючи вид атеросклеротичних бляшок, встановили, що у 25 (31,25\%) пацієнтів характеристика щільності бляшок за допомогою МДКТА збігалася з гістологічною верифікацією, прийнятою за «золотий стандарт». У 55 (68,75\%) пацієнтів спостерігали розбіжність між двома вказаними методами, зокрема, за допомогою МДКТА не візуалізовано початкових стадій ліпосклерозу з наявністю сполучнотканинних елементів. За наявності зрілої фіброзної бляшки з власними судинами та вогнищевим розростанням сполучної тканини обидва методи корелювали між собою щодо виду атеросклеротичних змін. Ускладнені бляшки, встановлені за допомогою МДКТА, під час подальшого мікроскопічного дослідження відповідали як стадіям атероматозу й атерокальцинозу, так і ліпосклерозу та виразкуванню. Таким чином, чутливість МДКТА у диференціації виду атеросклеротичної бляшки становила $31,3 \%$, специфічність - 100\%, точність - 45\%. Критерій $\chi^{2}$ Пірсона з поправкою Йєйтса дорівнював 6,750 (p=0,004) за мінімального значення очікуваного явища - 5,00; коефіцієнт зв'язаності Пірсона - 0,277, що свідчило про зв'язок середньої сили між інформативністю методу та результатом. ПНЦ становила 26,7\%; ППЦ - 100\%. Отже, МДКТА мала вельми високу специфічність, щоб диференціювати здорових осіб від хворих, але нижчу чутливість щодо визначення у пацієнтів виду атеросклеротичної бляшки порівняно з гістологічним дослідженням, прийнятим за «золотий стандарт», за допомогою якого навіть у певній вказаній стадіі чітко візуалізували початок чи зрілість названого патоморфологічного процесу.

Кореляційно-регресійним аналізом, який проводили для порівняння методів гістологічного дослідження та МДКТА аналогічних анатомічних структур, встановлено, що коефіцієнт кореляції Спірмена ( $\rho)$, взятий для ранжування кожної морфологічної стадії атеросклерозу, дорівнював 0,508. Зв'язок між досліджуваними ознаками (атеросклеротичними змінами, виявленими за допомогою морфологічної верифікації, та аналогічними результатами, отриманими під час проведення МДКТА) був прямим, сила зв'язку за шкалою Чеддока - високою. Число ступенів свободи (f) - 98, t-критерій Ст'юдента 13,232, критичне значення t-критерію Ст'юдента за даного числа ступенів свободи $-1,987 . \mathrm{t}_{\text {набл }}>\mathrm{t}_{\text {крит, }}$, алежність ознак статистично значуща ( $<<0,01)$. Слід зауважити, що до такого результату призвели помилки другого роду методу МДКТА, які були обумовлені складністю диференціації стадій атеросклерозу артерій.

Площа під ROC-кривою, за якою проводили кількісну інтерпретацію кривої помилок, для МДКТА становила 0,656 (p< 0,0001; 95\% довірчі інтервали (ДІ) обох методів не перехрещувалися), що свідчило про середню якість діагностичного тесту у визначенні стадії атеросклеротичної бляшки в порівнянні із «золотим стандартом». Досягнути рівня ідеального класифікатора завадили помилки другого роду, ціна яких, як відомо, є вищою, ніж похибок першого роду, у зв'язку з «пропуском» явища. Таким чином, зважаючи на відсутність похибок першого роду та враховуючи, що завданням дослідження була диференціація стадій атеросклерозу, а не власне наявність/відсутність бляшки в артерії, метод МДКТА можна достовірно статистично вважати клінічно цінним у діагностиці патологічних змін артеріального русла.

Під час вимірювання діаметра артерій на поперечному зрізі, площі поперечного перерізу, площі атеросклеротичної бляшки та співвідношення стінка/просвіт артерій похибки морфометрії у порівнянні із МДКТА, прийнятою за «золотий стандарт», були такими, що ними можна було знехтувати, тобто вони не виходили за межі впливних величин, до яких відносили температуру навколишнього середовища, атмосферний тиск, вологість повітря, що певним чином могли впливати на зміну просвіту та діаметра артерій. Таким чином, чутливість методу безпосередньої морфометрії артерій становила 90\%, специфічність - 85\%, точність - 89\%. Критерій $\chi^{2}$ Пірсона з поправкою Йєйтса дорівнював 44,083 (p < 0,001) за мінімального значення очікуваного явища - 5,00. Коефіцієнт зв'язаності Пірсона дорівнював 0,569 та свідчив про відносно сильний зв'язок між інформативністю методу та результатом. ПНЦ становила 68\%; ППЦ - 96\%.

Кореляційно-регресійним аналізом, який проводили для порівняння методів гістологічного дослідження та МДКТА аналогічних анатомічних структур, встановлено, що коефіцієнт кореляції Спірмена ( $\rho)$, взятий для ранжування безперервної шкали вимірюваних розмірів артерій, дорівнював 0,474. Зв'язок між досліджуваними ознаками (досліджуваними розмірами артерій, заміряними за допомогою прямої морфометрії, та аналогічними результатами, отриманими під час проведення МДКТА) був прямим, сила зв'язку за шкалою Чеддока - помірною. Число ступенів свободи (f) - 98, t-критерій Ст'юдента - 5,327, критичне значення $\mathrm{t}-$ критерію Ст'юдента за даного числа ступенів свободи - 1,987. $\mathrm{t}_{\text {набл }}>\mathrm{t}_{\text {крит, }}$, аалежність ознак статистично значуща ( $\mathrm{p}=0,000001)$. Дані показники кореляції пов'язані з наявністю $\alpha$ - та $\beta$-похибок методу безпосередньої морфометрії, які були обумовлені складністю штучного відтворення гомеостазу артеріального русла, що вплинуло на стан досліджуваних анатомічних структур. 
Порівняння характеристичних кривих помилок показало, що площа під ROC-кривою для безпосередньої морфометрії становила 0,875 (p < 0,0081; 95\% ДІ обох методів не перехрещувалися), що свідчило про дуже добру якість діагностичного тесту у визначенні анатомічних шуканих показників у порівнянні із «золотим стандартом». Показник площі під ROC-кривою для безпосередньої морфометрії був нижчим внаслідок восьми хибнонегативних та трьох хибнопозитивних результатів. Також методу МДКТА досягнути рівня ідеального класифікатора - $(0,0)-(0,1)-$ $(1,1)$ - перешкодила похибка другого роду. Отримані показники проведеного дослідження наочно демонструють основну перевагу інваріантності ROC-аналізу - розрахунок ціни похибки навіть «золотого стандарту» при побудові кривої та відтворення якості класифікатора.

Отже, за допомогою і методу МДКТА, і методу прямої морфометрії отримано високоінформативну кількісну оцінку анатомічних розмірів досліджуваних артерій, якщо зважати на статистично достовірні результати якості діагностичних тестів згідно з експертною шкалою класифікаторів.

\section{Обговорення}

«Золотим стандартом» для визначення виду атеросклеротичної бляшки залишається гістологічна верифікація, враховуючи детальну морфологічну характеристику патологічного процесу. Але з огляду на високу специфічність МДКТА, яка дає змогу виявити хворих, що справді мають атеросклеротичне ураження, і в такий спосіб уникнути гіпердіагностики, наявність похибок другого роду, що призвели до зниження чутливості, не є підставою для того, щоб зменшувати клінічну цінність рентгеноконтрастного методу. МДКТА, яку застосовують для диференціації виду атеросклеротичних бляшок, «не пропускає» захворювання як такого, тому є достовірним та високоінформативним методом діагностики для прогнозування подальшого лікування пацієнта.

Японські вчені (Department of Neurosurgery, Nagasaki University School of Medicine), які вивчали взаємозв'язок між МДКТА та гістологічним дослідженням, встановили позитивну кореляцію ( $\mathrm{r}=-0,56 ; \mathrm{p}<0,0001)$ під час діагностики атеросклеротичної бляшки, що містить фібрин, та негативну кореляцію ( $\mathrm{r}=-0,70 ; \mathrm{p}<0,001)$ при візуалізаціі бляшок з ліпідним ядром, в якому наявні вільний холестерин та його ефіри. Окрім того, менші неоваскуляризація та запалення були виявлені в бляшках з вищими денситометричними показниками згідно зі шкалою Хаунсфілда [6]

Порівняльну характеристику бляшок надали також датські вчені (Department of Radiology, Odense University Hospital). Вони дослідили, що мікрокальцифікацію не виявляє МДКТА. Не було встановлено зв'язку й між макрокальцифікацією та стабільністю бляшок, проте мікрокальцифікація була пов'язана із стійкими бляшками, що містять колаген. Результати дослідників корелюють з нашими висновками щодо прогностичного значення МДКТА для нестабільних бляшок, багатих ліпідами, у встановленні внутрішньобляшкового крововиливу та свідчать про високу кількість хибнопозитивних результатів на стадії формування фіброзної бляшки [7].
Наукові матеріали американських та італійських вчених містять інформацію про ураження ендотелію і гладком'язових клітин медії та наявність атеросклеротичних бляшок, яким при цукровому діабеті 2-го типу характерні підвищена кальцифікація та некротичні стрижні $[8,9]$. Отримані дані патогістологічної структури судинної стінки, ураженої атеросклеротичними змінами, корелюють 3 результатами румунських та американських вчених, які вивчали апоптоз клітин як основний реактивний механізм відповіді судинної стінки на пошкодження, що в пізніх стадіях призводить до розриву бляшки з подальшим формуванням тромбу [10, 11].

Швейцарські вчені (Cardiology Center, University Hospital, Geneva) вважають, що основна перевага морфометричного підходу полягає в тому, що просторова орієнтація судини по відношенню до підсилювача зображення не дуже важлива. Найбілыш серйозним обмеженням є те, що точність замірів можна отримати лише за допомогою виведення кругового просвіту, причому точність різко знижується із зменшенням діаметра судини. Під час МДКТА вимірювання набагато менше залежить від форми просвіту та правильної ідентифікації стінки судини на зображенні. Істотною перевагою є й те, що можна безпосередньо вимірювати і площу поперечного перерізу судини, і діаметр, який є менш важливим у зв'язку з низькою гемодинамічною відповідністю.

Проте строгі вимоги повинні бути виконані для встановлення потенційної точності МДКТА. Таким чином, морфометричний підхід вважають кращим для вимірювання абсолютного або відносного діаметра на інтактних судинах, тоді як МДКТА є більш точною у разі неправильного або малого просвіту. Морфометричне калібрування з використанням ін'єкційного катетера може викликати незначні помилки в обох підходах. У денситометричному підході «3D-калібрування» за допомогою куба відомих розмірів дає змогу також визначити орієнтацію судини в просторі [12].

Морфометричні заміри судин рідко можуть давати абсолютно однакові цифрові показники у порівнянні $з$ МДКТА. У даному дослідженні ймовірніше можна стверджувати про кореляцію обох методів з допустимими похибками. Це пов'язано із різним впливом зовнішніх (температура, вологість, атмосферний тиск) та внутрішніх (тиск кровотоку на судину in vivo, тиск введення ін'єкційної фарбувальної маси в біоматеріал та ії здатність до вазодилатації чи вазоконстрикціi) факторів на досліджуваний об'єкт, який, на відміну від твердих біоматеріалів, є еластичним.

\section{Висновки}

1. МДКТА має високу клінічну значущість у виявленні власне атеросклеротичних бляшок, але ії не можна вважати «золотим стандартом» щодо диференціації стадій атеросклерозу у пацієнтів з діабетичною макроангіопатією.

2. Пряма морфометрія артеріальних структур діабетичної стопи поступалась в операційних характеристиках МДКТА через складність штучного відтворення гомеостазу артеріального русла, що вплинуло на стан досліджуваних анатомічних структур. 


\section{References}

1. Carano RAD, Filvaroff EH. Angiogenesis and bone repair. DDT. 2003;21:980-9. doi: 10.1016/S1359-6446(03)02866-6.

2. Aragon-Sanchez J, Lazaro-Martinez JL, Cabrera-Galvan JJ. Additional information on the role of histopathology in diagnosing diabetic foot osteomyelitis. Diabetic Med. 2014; 31:113-6. doi: 10.1111/dme.12283.

3. Lepäntalo M, Apelqvist J, Setacci C, Ricco JB, de Donato G, Becker F, et al. Chapter V: Diabetic foot. Eur J Vasc Endovasc Surg. 2011;42:60 74. doi: 10.1016/S1078-5884(11)60012-9.

4. Matskevych VM, Pyptiuk VO, Dudii PF, Ryzhyk VM, Vasylyk VM, Mytsyk YuO, Sposib vstanovlennia rozmiriv diametra ta prosvitu arterii pry syndromi diabetychnoi stopy. Ukraine. Pat. 2017. 123876. [In Ukrainian].

5. Lilli R. Patogistologicheskaja tehnika i prakticheskaja gistohimija. Moskva:MIR; 1969. 645 p. [In Russian].

6. Horie N, Morikawa M, Ishizaka S, Takeshita T, So G, Hayashi K, et al. Assessment of carotid plaque stability based on the dynamic enhancement pattern in plaque components with multidetector CT angiography. Stroke. 2012;43:393-8. doi: 10.1161/STROKEAHA.111.635953.

7. Diab HMH, Rasmussen LM, Duvnjak S, Diederichsen A, Jensen PS, Lindholt JS. Computed tomography scan based prediction of the vulnerable carotid plaque. BMC Med Imaging. 2017;17:61. doi: 10.1186/ s12880-017-0233-5.
8. Siracuse JJ, Chaikof EL. The Pathogenesis of Diabetic Atherosclerosis. In: Shrikhande G., McKinsey J. (eds) Diabetes and Peripheral Vascular Disease. Contemporary Diabetes. Humana Press, Totowa, NJ. 2012:1326. doi: 10.1007/978-1-62703-158-5 2 .

9. Madonna R. Cellular and molecular mechanisms of vascular injury in diabetes - Part I: Pathways of vascular disease in diabetes. Vascul Pharmacol. 2011 Mar-Jun;54(3-6):68-74. doi: 10.1016/j.vph.2011.03.005.

10. Simionescu M, Sima AV. Morphology of Atherosclerotic Lesions. In: Wick G., Grundtman C. (eds) Inflammation and Atherosclerosis. Springer-Verlag/Wien. 2012:19-37. doi: 10.1007/978-3-7091-0338-8 2.

11. Fotiadis N, Kyriakides C, Bent C, Vorvolakos T, Matson M. 64-section $\mathrm{CT}$ angiography in patients with critical limb ischemia and severe claudication: Comparison with digital subtractive angiography. Clin Radiol. 2011;10:945-52. doi: 10.1016/j.crad.2011.04.015.

12. Doriot PA, Guggenheim N, Dorsaz PA, Rutishauser W. Morphometric versus densitometric assessment of coronary vasomotor tone-an overview. Eur Heart J. 1989 Nov;10 Suppl F:49-53. doi: 10.1007/ bf01137533. 